PAEDAGOGIA ChristianA

2/24 (2009) - ISSN 1505-6872

Anna Więctawska*

Toruń

\title{
Ojcostwo w świecie współczesnym
}

Rodzina jest kamieniem węgielnym społeczeństwa ${ }^{1}$. To podstawowa grupa społeczna, występująca we wszystkich historycznie znanych typach społeczeństw i kultur. Składa się z małżonków (kobiety i mężczyzny), ich dzieci (także adoptowanych) oraz krewnych małżonków (są dla siebie powinowatymi). Rodzina odgrywa główną rolę w procesie socjalizacji². Stanowi podstawową formę, umożliwiającą egzystowanie poszczególnych jednostek oraz funkcjonowanie całego społeczeństwa. Rodzinę tworzy strukturalizowany i funkcjonalnie powiązany zbiór jednostek i specyficznych substruktur oraz mikroelementów społecznych, kształtujących mikrogrupę i zarazem instytucję społeczna, powiązaną wewnętrznie więzią małżeńską, więzią pokrewieństwa, powinowactwa lub adopcji oraz wypełniających jednocześnie wiele istotnych, ważnych, zintegrowanych ze sobą funkcji wobec jednostek i społeczeństwa, opierających się na regulatorach występujących w kulturze behawioralnej ${ }^{3}$.

Rodzina w czasach dzisiejszych znajduje się pod wpływem rozległych, głębokich i szybkich przemian społecznych i kulturowych. Wiele rodzin przeżywa ten stan rzeczy, dochowując wierności tym wartościom, które stanowią fundament instytucji rodzinnej. Inne stanęly niepewne i zagubione wobec swych zadań, a nawet niekiedy zwątpiły i niemal zatraciły świadomość ostatecznego znaczenia i prawdy życia małżeńskiego i rodzinnego. Inne jeszcze, na skutek

* Dr Anna Więcławska, adiunkt na Wydziale Nauk Pedagogicznych Uniwersytetu Mikołaja Kopernika w Toruniu.

${ }^{1}$ E. Willock, Rola ojca w rodzinie katolickiej, Sandomierz 2007, s. 7.

2 Encyklopedia Popularna PWN, Warszawa 1995, s. 728.

3 D. Gębuś, Rodzina. Tak, ale jaka?, Warszawa 2006, s. 23; zob. także: Z Tyszka, System metodologiczny wieloaspektowej integralnej analizy życia rodzinnego, Poznań 2001, s. 43. 
doznawanych niesprawiedliwości, napotykają na przeszkody w korzystaniu ze swoich podstawowych praw ${ }^{4}$.

Współczesna rodzina przeżywa w ostatnich latach kryzys. Jest ona w coraz większym stopniu narażona na niebezpieczeństwa, tkwiące zarówno w środowisku rodzinnym, jak i pozarodzinnym. Współczesna rzeczywistość nie sprzyja rodzinie 5 .

Znaczącym elementem, towarzyszącym kryzysowi rodziny, jest kryzys ojcostwa, czyli kryzys kariery typowo męskiej. Niespełnione ojcostwo jest zasadnicza, choć często nieuświadomioną przyczyną braku szczęścia w życiu mężczyzny ${ }^{6}$. Współczesny kryzys rodziny łączy się w znacznej mierze z zakwestionowaniem roli, jaką powinien w rodzinie odgrywać mąż i ojciec ${ }^{7}$.

Jakie jest więc współczesne ojcostwo? Jacy są współcześni ojcowie i czego się od nich oczekuje? Jakie są przejawy kryzysu ojcostwa? Czy i jakie są możliwości jego przezwyciężenia? Jak objawia się nowy paradygmat męskości i ojcostwa?

\section{Ważność osoby ojca w rodzinie a jego brak}

W tradycyjnym paradygmacie męskości i ojcostwa mężczyzna był twórca kultury, panował nad wszystkim, realizował się w męskich dziedzinach. Było tak na całym świecie. Kobiety miały o wiele niższą pozycję. Zajmowały się rodzeniem dzieci, opieką nad nimi i prowadzeniem domu. Uważano to za mniej odpowiedzialne zadania. Na taki podział, z uwzględnieniem płci, miała wpływ filozofia grecka i religia judeochrześcijańska. Urodzenie się chłopcem było gwarancją uprzywilejowanej pozycji w społeczeństwie. Uważano, że męskość jest raz na zawsze ustalona, bo wynika z biologii. W tradycyjnych założeniach męskości mężczyźni nie mogli wyrażać swoich uczuć. Mogli oni jedynie polegać na racjonalnym i ilościowym myśleniu. Ta uprzywilejowana pozycja mężczyzn to wynik wyjątkowych zdolności i predyspozycji. Wielu mężczyzn boi się utracić tę uprzywilejowaną pozycję w społeczeństwie i władzę, dlatego tradycyjny paradygmat męskości wciąż mocno się trzymå .

${ }^{4}$ Jan Paweł II, Familiaris consortio, nr 1, w: K. Lubowicki (red.), Posoborowe dokumenty Kościoła Katolickiego o matżeństwie i rodzinie, t. I, Kraków 1999, s. 158.

${ }_{5}^{5}$ D. Ruszkiewicz, Realizacja funkcji opiekuńczo-wychowawczej w rodzinie samotnego ojca, Toruń 2005, s. 28.

${ }^{6}$ J. Pulikowski, Czy w dzisiejszych czasach warto być ojcem?, w: D. Kornas-Biela (red.), Oblicza ojcostwa, Lublin 2001, s. 95.

7 J. Nagórny, Posłannictwo ojca w kontekście wspótczesności, w: D. Kornas-Biela (red.), dz. cyt., s. 61 .

${ }^{8}$ K. Arcimowicz, Obraz mężczyzny w polskich mediach. Prawda. Fatsz. Stereotyp, Gdańsk 2003, s. 55-56. 
W rodzinie tradycyjnej każdy pełnił jakąś funkcję, każdy miał swój zakres praw i obowiązków. W rodzinie chłopskiej funkcjonował wyraźny podział na czynności męskie i kobiece. Mąż oczywiście dominował nad żoną i dziećmi. Kobieta oprócz zajmowania się wszystkimi pracami domowymi musiała jeszcze pomagać mężowi w gospodarstwie. Mąż wykonywał najcięższe prace, a także wyznaczał prace poszczególnym członkom rodziny i nadzorował je. Żona oraz dzieci musieli być mu posłuszni oraz zgadzać się z jego wolą. Jego rola w rodzinie była główna i kierownicza. Małżonkowie mieli wzajemny obowiązek wierności i dbałości o siebie, ponadto mężczyzna musiał uwalniać kobiety od ciężkich prac. Tradycyjne małżeństwo opierało się na wspólnym interesie. Był to trwały i stały związek, mający charakter instytucji, w której panowały materialno-rzeczowe stosunki między małżonkami, potrzebującymi siebie nawzajem. W wielu przypadkach rodzice kojarzyli małżonków, ponieważ ważniejszy był dla nich aspekt ekonomiczny niż wzajemne uczucie przyszłych małżonków. Dzieci były traktowane jako siła robocza, już od najmłodszych lat musiały pomagać $\mathrm{w}$ gospodarstwie. Im więcej dzieci, tym więcej rąk do pracy. Były one również zabezpieczeniem i opieką na starość. Traktowano je przedmiotowo, jako kategorię ekonomiczną. Relacje ojciec-dzieci były bardzo zdystansowane, ograniczały się do realizowania zadań, które wyznaczył im ojciec do wykonania w domu bądź w gospodarstwie. W rodzinie robotniczej lub inteligencko-mieszczańskiej mąż także dominował nad żoną i dziećmi, był głową rodziny i jej żywicielem. Do żony należały wszystkie obowiązki domowe, takie jak między innymi sprzątanie, pranie, przygotowywanie posiłków.

Musiała ona wspierać męża w działaniach, a także dbać o jego dobro, była również towarzyszką jego życia, stała u jego boku. Dobra żona to zarazem dobra matka. Powinna umieć podporządkować się mężowi, a także być pracowita, gospodarna oraz troskliwa. Opiekowała się dziećmi i wychowywała je w tradycji rodzinnej i religijnej. Obdarzała je ciepłem i miłością, zaspokajała ich potrzeby psychiczne i fizyczne oraz zapewniała im poczucie bezpieczeństwa. Mąż natomiast musiał pracować, żeby utrzymać rodzinę. Powinien mieć dobry zawód lub pracę i być pracowity oraz zaradny, a także powinien być ojcem, który dba o rodzinę. Był również konsekwentny i stanowczy oraz utrzymywał dyscyplinę wśród dzieci, czyli egzekwował przestrzeganie pewnych zasad. Wprowadzał on także dzieci w świat wartości i norm społecznych. W jego rolę była wpisana władza i autorytet oraz podejmowanie najważniejszych decyzji dotyczących wychowania dzieci oraz życia rodzinnego, a także pracowitość, czyli właściwie ciężka praca dla zapewnienia bytu rodzinie. W takiej rodzinie dziecko stanowiło większą wartość dla rodziców niż w rodzinie chłopskiej. Było ono przedmiotem większej troski i miało więcej praw w rodzinie, a także rodzice dbali o jego potrzeby i wykształcenie, szczególnie w rodzinie inteligencko-mieszczańskiej9.

${ }^{9}$ D. Gębuś, dz. cyt., s. 51-54. 
W dzisiejszej kulturze większość mężczyzn jest do pewnego stopnia pod wpływem modelu biernego, niezaangażowanego, nieobecnego ojca. Społeczeństwo zbyt często nie docenia niezastąpionej roli ojca w życiu swoich dzieci. Ojca uważa się jedynie za osobę dostarczającą rodzinie funduszy do prowadzenia gospodarstwa domowego, wyżywienia i ubierania dzieci. Jeszcze bardziej tragiczne jest to, że w niektórych kręgach społecznych uważa się go za niepotrzebnego w życiu dziecka. Dwie wojny światowe, kryzys ekonomiczny, walczący feminizm, łatwy dostęp do środków antykoncepcyjnych, media, modne trendy i napięte terminy w pracy wraz z innymi problemami społecznymi przyczyniają się do tego, że ojcostwo jest zagrożone ${ }^{10}$.

Współczesny kryzys ojcostwa decydująco wpłynął na zmianę roli mężczyzny w rodzinie. Miejsce ojca wszechwładnego zajął ojciec zdystansowany. Nie sprawuje on już władzy nad „swoimi ludźmi”, ale nie jest też aktywnym partnerem. W praktyce ojcostwo nie wydaje się związane ani z wielkim wysiłkiem, ani ze szczególnym zaangażowaniem. Prawdopodobnie dlatego wielu ojców i dzieci ze wszystkich grup wiekowych jest sobie obcych. Ojcowie nie są tego świadomi. Naiwnie sądzą, że jako „żywiciele rodziny”, sędziowie w rodzinnych konfliktach, towarzysze zabaw i spacerów wypełnili swoje powinności ${ }^{11}$.

Dzieci potrzebują ojca, potrzebują ojcowskiej miłości dla swojego rozwoju. Prawdę tę w sposób bolesny potwierdzają wszystkie błędy wychowania, w których na sposób zewnętrzny lub wewnętrzny zabrakło współuczestnictwa ojca w dziele wychowania (a szerzej - dziele kształtowania całości relacji rodzinnych i atmosfery domu). Błędy te dotyczą zarówno relacji do córek, jak i synów, ale - jak się wydaje - szczególnie dramatycznie nieobecność ojca w dziele wychowania odbija się dzisiaj na osobowości młodego mężczyzny ${ }^{12}$.

Ze społecznego punktu widzenia jedną z najpoważniejszych szkód spowodowanych przez zanik praktyk inicjacyjnych w męskim świecie jest stopniowa utrata przez młodych mężczyzn umiejętności kontrolowania poziomu swojej agresji oraz jej właściwego ukierunkowania. Istotnie, właśnie nauczenie się tej kontroli było jednym z podstawowych aspektów owych praktyk. Skutki tego zaniku są aż nadto widoczne ${ }^{13}$.

Proces zanikania roli ojca jako tego, który pomaga synowi we właściwym wykorzystaniu i ukierunkowaniu jego energii oraz wtajemnicza go w życie społeczne, oznacza zerwanie antropologicznego związku między człowiekiem a dawniejszą męską kulturą ${ }^{14}$.

\footnotetext{
${ }^{10}$ J. Augustyn, Ojcostwo. Aspekty pedagogiczne i duchowe, Kraków 2003, s. 22.

${ }^{11}$ Tamże, s. 20-21.

12 J. Nagórny, dz. cyt., s. 76.

${ }^{13}$ C. Rise, Ojciec. Niezgoda na nieobecność, Kielce 2005, s. 60.

${ }^{14}$ Tamże, s. 57.
} 
Ojciec kocha dziecko na swój własny sposób, inaczej niż kobieta. Nie jest to bez znaczenia dla dziecka. Ojciec może ofiarować mu coś, czego nie może dać mu matka ${ }^{15}$. Ojcowie są tak samo nie do zastąpienia, jak matki ${ }^{16}$.

Dla ludzkiej psychiki ogromnym ułatwieniem w osiagnięciu poziomu pełnego rozwoju psychicznego i uczuciowego jest obecność ojca w domu. Chodzi o obecność ojca zarówno jako konkretnej osoby, jak też jako ojcowskiego pierwiastka, którego istotne znaczenie powinno być przez społeczeństwo uznane. Kiedy zaś ojciec zostaje fizycznie i symbolicznie „odepchnięty”, pełny rozwój osobowości człowieka jest osiagany z wielkim trudem i tylko epizodycznie, a jednostka nie potrafi nigdy oderwać się od poprzednich poziomów psychologicznych, jakich doświadcza $\mathrm{w}$ dzieciństwie ${ }^{17}$.

Nieobecność ojca, jako postaci wprowadzającej w świat norm i zasad, ułatwia ześlizgnięcie się w świat, w którym nie obowiązują żadne reguły oraz wprowadza w tę obojętną bierność sprzyjającą nadużyciom i poprzedzającą je. Stąd ciąża przed- i pozamałżeńska wśród młodych kobiet, przy jednoczesnej nieobecności ojców, to najczęstszy symptom zapowiadający przyszłe nadużycia wobec dzieci ${ }^{18}$. Zniknięcie ojca utrudnia, jeśli nie uniemożliwia, znoszenie zranień spowodowanych przez straty i porażki, towarzyszące przemianie i rozwojowi człowieka ${ }^{19}$.

Społeczeństwo potrzebuje autentycznych ojców. Bez uznania roli ojca mężczyźni nie mają żadnej motywacji do włączania się we wspólnotę społeczną jako świadomi swej odpowiedzialności obywatele, do konstruktywnego wykorzystywania swoich zdolności dla dobra ogółu i opanowania agresji, uczynienia czegoś dla przyszłego pokolenia ${ }^{20}$.

Ojciec zaświadcza, że życie nie jest tylko zaspokojeniem i potwierdzeniem pozytywności istnienia, ale również utratą, brakiem, trudem. Najgłębsze ludzkie doświadczenia, poczynając od miłości, mają swoje źródło i są kształtowane właśnie przez stratę. Ojciec wnosi w życie człowieka naukę o zranieniu, gdyż jego podstawowym psychologicznym i symbolicznym zadaniem jest nadawanie kształtu, ukazywanie celu temu wszystkiemu, w czym dziecko było zanurzone w pierwotnej relacji do matki, a co samo przez się zmierzałoby do kontynuacji istnienia. Dlatego ojciec powoduje pierwsze uczuciowe i psychologiczne zranienie, wkraczając w symbiozę z matką (w jakiej dziecko pozostaje do chwili, gdy ojcowska interwencja staje się życiową koniecznością) i ukazując od tego momentu rozwijającemu się dziecku kierunek, proponując mu pewien teleos, pewną perspektywę. Każda perspektywa skupia spojrzenie na niektórych kierunkach,

\footnotetext{
${ }^{15}$ H. Bullinger, Mężczyzna czy ojciec, Warszawa 1997, s. 188.

16 Tamże, s. 191.

${ }^{17}$ C. Rise, dz. cyt., s. 103.

18 Tamże, s. 112.

19 Tamże, s. 118.

${ }^{20}$ H. Bullinger, dz. cyt., s. 191-192.
} 
pomijając inne. Ceni pewne zachowania, a innymi gardzi. Stąd oddziaływanie ojca początkowo ogranicza życie młodego człowieka, „rani” go, by uczynić silniejszym. Jest to ciężki, trudny i emocjonujący etap wychowania. Dziecko uczy się wówczas wyrzeczenia ${ }^{21}$.

Brak ojców w rodzinie ma określone konsekwencje społeczne. Z nieobecnym ojcem chłopiec nie może się identyfikować. Brak mu przykładu ojcostwa, który mógłby wykorzystać we własnym życiu. Bycie ojcem nie wydaje mu się potem warte wysiłku. Tak wychowywani synowie albo całkowicie odrzucają rolę ojca, albo kopiują w swoim życiu rolę ojca jako osoby nieobecnej. Kiedy nie ma ojca, nikt nie może przekazać synowi, jaką radością i wysiłkiem jest ojcostwo. Trudno będzie tym chłopcom stać się w przyszłości ojcami. Będą czuli się niepewnie w tej roli. Nigdy nie mieli bowiem wzoru, który mogliby naśladować2 ${ }^{22}$.

Z psychologicznego punktu widzenia cena zapłacona za odrzucenie oddzielenia dziecka od matki i wzniesienia go ku niebu, dokonywane przez ojca, staje się de facto rezygnacją z budowania społeczeństwa ludzi dorosłych. Dzisiejsze „wieczne dzieci”, mężczyźni i kobiety, pozostają przez całe życie na horyzontalnym poziomie potrzeb, jako więźniowie niekończącego się dzieciństwa, pechowo naznaczonego depresją i neuroza, które uderzają w człowieka za każdym razem, gdy tylko łamie on prawa natury ${ }^{23}$.

Dziecko wchodząc w relacje $\mathrm{z}$ ojcem, $\mathrm{z}$ dorosłym mężczyzną, nosicielem norm, doświadcza, że nie jest wszechmocne, że jest ograniczone normami, czasami dość dla niego przykrymi, które powinno respektować ${ }^{24}$.

Czynna, troskliwa obecność ojca jest ważna od pierwszych dni życia dziecka i tak będzie już zawsze i na zawsze ${ }^{25}$. Istotą ojcostwa jest miłość i odpowiedzialność, ze szczególnym akcentem na odpowiedzialność. Odpowiedzialna miłość ojcowska powinna wyrażać się altruistyczną troską o wszechstronny rozwój wszystkich członków rodziny oraz dbałością o to, by wszystko w rodzinie zmierzało do wyznaczonego, wartego poświęcenia życia, celu ${ }^{26}$.

Bycie ojcem nie ogranicza się tylko do właściwych więzi z własnymi dziećmi, że dobrym ojcem można być w pełni wtedy, jeśli odpowiedzialnie podchodzi się do wszystkich relacji, które składają się na wspólnotę rodzinną. Nie można być w pełni dobrym ojcem, jeśli nie jest się dobrym synem dla własnych rodziców, jeśli nie szanuje się rodziców żony. Nie można być dobrym ojcem, jeśli nie jest się dobrym mężem. W punkcie wyjścia należy zawsze pytać o miłość małżeńską, z którą wiąże się głęboki szacunek dla równej godności kobiety i dzięki której tworzy się szczególna forma „,przyjaźni osób”. Miłość do małżonki, która

\footnotetext{
${ }^{21}$ C. Rise, dz. cyt., s. 10-11.

${ }^{22}$ H. Bullinger, dz. cyt., s. 194-195.

${ }^{23}$ C. Rise, dz. cyt., s. 19.

24 Tamże, s. 23.

${ }^{25}$ H. Bullinger, dz. cyt., s. 192.

${ }^{26}$ J. Pulikowski, dz. cyt., s. 96.
} 
została matką i miłość do dzieci są dla mężczyzny naturalną drogą do zrozumienia i urzeczywistnienia swojego ojcostwa. Tam, gdzie warunki społeczne i kulturalne łatwo skłaniają ojca do pewnego uwolnienia się od zobowiązań wobec rodziny i do mniejszego udziału w wychowaniu dzieci, konieczne jest odzyskanie społecznego przekonania, że miejsce i zadanie ojca w rodzinie i dla rodziny mają wagę jedyną i niezastąpioną. Znaczenie relacji małżeńskich, a więc stosunku męża do żony, w wypełnianiu powołania do ojcostwa jest nie do przeceniania ${ }^{27}$.

\section{Nieobecność i dewaluacja znaczenia ojca przejawami kryzysu}

Według Steve Biddulph, wciąż obecne dawne wzorce roli ojca ograniczają możliwości realizowania współczesnego wzorca ojcostwa i negocjowania jego wymiaru. Autor wyróżnił cztery kategorie wadliwych ojców z przeszłości ${ }^{28}$.

Pierwsza kategoria to „niedoszły król”. To mężczyzna pracujący przez cały dzień, który wracał, zasiadał w fotelu i rządził wszystkimi. Żonę traktował jak służąca, a dzieci nie słuchał. Wszyscy jak poddani usługiwali mu, by nie przeszkadzać. Matki często straszyły nim dzieci, ponieważ jego rola w wychowaniu dzieci ograniczała się do karania lub ułaskawiania. Król domostwa.

Do następnej kategorii - „ojca krytycznego” - zaliczył ojca aktywnego w przykry i negatywny sposób. Zły i sfrustrowany ciagle szuka dziury w całym i upokarza innych. Nie jest on świadomy, jak krzywdzi swoich bliskich, wydaje mu się, że pomaga, a niestety domownicy go nienawidzą, bo nie daje nic dobrego. W pewien sposób rozładowuje na domownikach swoje niepowodzenia, brak sukcesów czy problemy z własnym ojcem. Stale upokarza innych, napędzany własną frustracją i złością.

„Ojciec bierny” daje władzę żonie, rezygnuje ze swoich powinności i obowiązków, brakuje mu charakteru. Można go często zobaczyć w warsztacie pracy, przed telewizorem lub z gazetą. Znienawidzony przez dzieci, szczególnie przez synów. Wszystkim ustępuje, tylko czasem traci panowanie, narzeka. Można powiedzieć, że nigdy go nie było.

„Ojciec nieobecny” jest silnym człowiekiem, kompetentnym, ale poza domem i rodziną. Często jest w pracy, pilnuje kariery. Jest mocno zaangażowany w pracę, która go całkowicie pochłania. Od świtu do późnego wieczora jest nią zajęty. Jest życzliwy i miły dla swoich dzieci, zaspokaja ich potrzeby materialne, ale nie przekazuje im swoich wartości, nie spędza z nimi czasu, jest im obcy.

Ojciec może być nieobecny przynajmniej na dwa sposoby: fizycznie i psychicznie. Ilu ojców jest nieobecnych fizycznie? Co siódma rodzina jest niepełna i dzieci wychowuje tylko matka. Kilkanaście procent wychowuje się bez ojca. Przyczyny fizycznej nieobecności są różne, czasem przez nikogo niezawinione,

\footnotetext{
${ }^{27}$ J. Nagórny, dz. cyt., s. 70-71.

${ }^{28}$ S. Biddulph, Męskość, Poznań 2004, s. 83-84.
} 
na przykład jego śmierć. Nieobecność ojca może być też zawiniona, na przykład przez matkę, jeżeli kobieta chce mieć dziecko, będąc panną, po to, żeby mieć kogoś dla siebie, żeby mieć coś własnego, co daje jej sens życia, i nie oglądając się na konsekwencje dla dziecka, rodzi dziecko bez ojca. Po drugie - przez matkę również wtedy, gdy jej zachowanie uniemożliwia ojcu dziecka życie wspólne $z$ rodziną. Po trzecie - przez niego samego, i ta sytuacja jest chyba najczęstsza. Ojciec powołuje dziecko do życia i więcej się nim nie przejmuje. Jest nieobecny, nawet jeśli pozoruje opiekę przez płacenie alimentów i odwiedziny raz na jakiś czas. Przyznając, że różne mogą być przyczyny nieobecności ojca, trzeba powiedzieć, że skutki są podobne - dziecko nie ma ojca. Niezależnie od przyczyn ta sytuacja jest niekorzystna dla wszystkich osób w niej uczestniczących. Przede wszystkim dla dziecka, bo pozbawia je jednej z dwu najważniejszych dla niego osób, pozbawia je wzoru męskiego. Ojciec pozbawiony jest w tej sytuacji szansy rozwoju, jaką daje ojcostwo: bezwarunkowej, ofiarnej miłości. Matka zaś, będąc samotna, nieraz nieszczę́liwa, zmienia się także jako matka. Często samotne matki są nadopiekuńcze, częściej niż inne wchodzą z dzieckiem w symbiozę, nie umieją dać mu wolności, mają tendencje do przetrzymywania dzieci przy sobie itp.

Oprócz nieobecności fizycznej ojca istnieje jeszcze jego nieobecność psychiczna. Trudno określić, jak często ona występuje, gdyż brak odpowiednich badań na ten temat. Można jednak sądzić, że jest ona częstsza niż nieobecność fizyczna. Są ojcowie, którzy trwają w rodzinie, ale psychicznie są nieobecni. Dzieje się tak z wielu powodów. Pierwszym z nich jest tradycyjny, sztywny podział ról rodzinnych, który w dzisiejszych czasach niezbyt się sprawdza: matka opiekuje się dziećmi, a ojciec jest nieobecny w domu, gdyż zarabia. Wychodzi rano, kiedy dzieci jeszcze śpią, i wraca, kiedy już śpią. Nie ma z nimi kontaktu i jeżeli raz na jakiś czas nagle zaczyna pełnić funkcję ojca, nie umie z nimi rozmawiać. W takiej sytuacji dzieci praktycznie nie mają ojca. Ojciec, pracując wprawdzie w swoim zawodzie, może kształtować w sobie takie właściwości, jak energia czy przedsiębiorczość, ale nie rozwija innych ważnych cech, gdyż rzadko w pracy zawodowej ma okazję rozwinąć wyrozumiałość, czułość, łagodność, cierpliwość, delikatność itp. Właśnie rodzina jest najlepszym polem do rozwoju tych cech. Nieobecność psychiczna ojca jest niekorzystna dla wszystkich trzech zainteresowanych osób.

Nieobecność psychiczna może również wynikać z błędu w interakcji między rodzicami. Bywa, że żona wszystko robi sama, o wszystkim decyduje. Mąż wobec tego nie czuje się w domu potrzebny, przyzwyczaja się do sytuacji i dystansuje się do spraw domowych.

Nieobecność psychiczna ojca może też wynikać nie z jego złej woli, lecz $\mathrm{z}$ błędów porozumiewania się małżonków, powodujących odsuwanie męża od spraw domowych. Ojciec jest obecny, oboje rodzice chcą dobrze, ale nie umieja rozwiązać problemu podziału obowiązków i odpowiedzialności. Jeśli taka sytuacja nie zostanie rozwiązana pozytywnie, trudności powiększają się i między 
małżonkami rośnie obcość, która dość często prowadzi do rozpadu rodziny ${ }^{29}$. Na przestrzeni minionego stulecia wraz z dewaluacją złotówki zdewaluowała się wartość ojcostwa ${ }^{30}$.

Dorota Kornas-Biela wymienia kilka typów ojców, które potwierdzają zjawisko dewaluacji znaczenia ojca w rodzinie i zmiany jego roli. Są to:

1) ojciec - męska mama,

2) ojciec na ,ławce rezerwowych”,

3) mężczyzna ,wykastrowany”,

4) ojciec tragiczny,

5) ojciec inseminator,

6) mężczyzna - nieodpowiedzialny „facet”: rozbita ojcowska tożsamość.

Partnerski styl życia rodzinnego zatarł w dużym stopniu charakterystyczne cechy roli męża i ojca. Tradycyjnemu modelowi ojca przypisuje się despotyzm i okrucieństwo (w ręku nieodłączny pas), chłód uczuciowy i brak zainteresowania dziećmi (ograniczenie jego roli do spłodzenia). Tradycyjne ojcostwo ujmuje się jako panowanie opresora, stąd w czasach, gdy upadły wszelkie monarchie, taki układ sił zdaje się anachronizmem. Demokracja w państwie domaga się demokracji w rodzinach. Przeciwieństwem tradycyjnego ojca miał być ojciec ,partner żony”, współpracujący z nią na zasadzie demokratycznego podziału ,zysków i strat", obowiązków i przywilejów. Realizacja pragnienia ojcostwa wiąże się tutaj z rezygnacją ze specyfiki ojcostwa. Ojciec staje się ojcem postmodernistycznym, czyli bezpłciowym rodzicem, rodzicem androgenicznym, ojcem matkującym dziecku wraz z matką ojcującą dziecku. Ojciec zdegradowany w rodzinie z pozycji autorytetu traktowany jest najczęściej jako ,przydatna ciocia” lub jako „druga mama”, „męska mama”, pomagająca matce spełniać jej funkcje pielęgnacyjno-wychowawcze wobec dzieci. Uzupełnia żonę w pracach domowych, nadrabia niedomogi jej macierzyńskiego instynktu lub podejmuje tradycyjne role męskie wtedy, gdy matka nie jest w stanie im podołać, w przeciwnym razie wykonałaby to sama. Jednak nie każdy mężczyzna - i nie w każdej sytuacji życiowej - czuje się przygotowany do tej podwójnej roli. Stawiane przed nim zadania mogą budzić poczucie niekompetencji. Nowe oczekiwania związane z jego poszerzoną o macierzyńskie zadania rolą ojcowską mogą rodzić również niepokój, zagubienie, a nawet złość. Nieobecny jako „głowa rodziny” i autorytet ojciec oraz silna i dominująca matka to sytuacja sprzyjająca wychowaniu słabych i uległych mężczyzn, którzy w następne pokolenia wnoszą model funkcjonowania ojca jako „niepotrzebnego mebla” w domu. Partnerstwo w małżeństwie powinno być więc prawidłowo zrozumiane, by nie stwarzać niebezpieczeństw w funkcjonowaniu rodziny.

Ojciec we współczesnych społeczeństwach został zepchnięty na margines życia rodzinnego lub nawet odstawiony poza nie. Świadczy o tym między innymi

${ }^{29}$ M. Braun-Gałkowska, Być ojcem, w: D. Kornas-Biela (red.), dz. cyt., s. 201-203.

${ }^{30}$ D. Kornas-Biela, Wstęp, w: taż (red.), dz. cyt., s. 9. 
osłabienie roli ojca jako przekaziciela „rodzinnej schedy zawodowej”. Partnerski układ podziału ról w rodzinie zdegradował ojca z pozycji „głowy rodziny”, najważniejszego rodzinnego menadżera, opiekuna, protektora, „bastionu obrony”, żywiciela, decydenta, egzekutora, arbitra. Nie odgrywa on już tej roli w rodzinie ani też nie oczekuje się tego od niego. Kryzys ojcostwa polega więc nie tylko na częstym braku ojca w rozwoju dziecka, ale również na niedocenianiu jego obecności, na coraz powszechniej akceptowanym twierdzeniu, że ojciec nie jest koniecznie potrzebny dzieciom, a nawet jest lepiej, gdy go nie ma. Postrzegany w domu jak ,kochana ciocia” nie jest tym samym traktowany jako osoba znacząca i nieodzowna dla istnienia wspólnoty rodzinnej. Okazuje się, że na „boisku życia" ojciec nie tylko sam schodzi z pola, ale bywa też usunięty i ewentualnie podmieniony przez innego, który wejdzie w jego rolę, starając się zagrać ją lepiej. W tym kontekście widać, że ojcostwo pojmuje się jako bardziej związane z pełnioną w rodzinie funkcją względem dziecka niż z osobą konkretnego mężczyzny. Aktualny partner matki jest ojcem dla dziecka, chociaż nie jest on ojcem biologicznym. Tak więc wprowadza się tu zamieszanie w rozumieniu istoty ojcostwa.

Kryzys ojcostwa przejawia się także w fakcie braku możliwości zostania przez mężczyznę ojcem bez zgody kobiety, na skutek stosowanej przez nią antykoncepcji. Dramatycznym przykładem wskazującym na utratę znaczenia ojcostwa jest aborcja. Jest ona także przyzwoleniem na zwalnianie mężczyzny $\mathrm{z}$ opieki nad swoim potomstwem. Utrata dziecka to utrata realnego ojcostwa, spełniającego się w interakcji z dzieckiem.

Ekstremalnym przykładem zepchnięcia idei ojcostwa na margines oraz dewiacji, wynaturzenia, a wręcz samobójstwa ojcostwa, jest ojciec inseminator mężczyzna oddający swoje nasienie do banku spermy. Rozwój usług związanych ze sztucznym zapłodnieniem jest społecznym sygnałem kierowanym do mężczyzn, iż stają się coraz mniej potrzebni jako osoby, natomiast kobietom może być potrzebny produkt ich ciała. Fakt istnienia banków spermy sprzyja antagonizowaniu płci - dzięki oferowanym przez nie usługom kobieta może mieć dziecko, jeśli sobie tego życzy, natomiast mężczyzna nadal potrzebuje do tego zgody kobiety. W ten sposób ,produkuje się” dzieci bez ojców i bez prawa do informacji o tym, kto jest ich ojcem. W tym przypadku nie można nawet powiedzieć, że rola ojca ograniczyła się do zapłodnienia, bo nie brał on w nim udziału, a nawet nie wie, kto jest matką dla jego dziecka, komu oddał żywotną cześć siebie i zupełnie go to nie interesuje. Wskazuje to na regresję kultury oraz na końcowy etap degradacji społeczeństwa, które przez wieki wypracowywało model ojca odpowiedzialnego za swoje potomstwo ${ }^{31}$. Najskrajniejszą formą przeświadczenia, że dzieci nie potrzebują ojca, jest handel spermą ${ }^{32}$.

${ }^{31}$ D. Kornas-Biela, Współczesny kryzys ojcostwa, w: taż (red.), dz. cyt., s. 174-188.

${ }^{32}$ J. Augustyn, dz. cyt., s. 25. 


\section{Potrzeba odbudowy ojcostwa. Nowy paradygmat ojcostwa}

Ojcostwo przeżywa dzisiaj głęboki kryzys. Wypływa on nie tylko z postaw i zachowań samych mężczyzn, ale także z kryzysu małżeństwa i rodziny, które są fundamentem dojrzałego i odpowiedzialnego ojcostwa. I choć wielu mężczyzn pogubiło się w pełnieniu swojej ojcowskiej roli, nie zatracili oni jednak głębokiego pragnienia posiadania i wychowania dzieci. Umarł w naszych czasach jedynie pewien model ojcostwa. Nie jest to już silny autorytet pana rodziny i niepodlegająca dyskusji wyrocznia. Ojcostwo jawi się dzisiaj bardziej jako służba dzieciom. Stąd też trzeba mówić nie tyle o funkcji czy roli ojcowskiej, odtwarzanej z pokolenia na pokolenia, ile raczej o misji i powołaniu, które - jak nigdy dotąd - domaga się osobistego zaangażowania, woli zmagania się z sobą, prawdziwej męskiej, twórczej postawy oraz powrotu do duchowości i religijności. Analizując bowiem kryzys małżeństwa i życia rodzinnego, a w konsekwencji także ojcostwa, należy podkreślić, że najgłębszą jego przyczyną jest kryzys współczesnego człowieka $^{33}$.

Szukanie przyczyn kryzysu ojcostwa jedynie w niedojrzałości emocjonalnej czy moralnej mężczyzn oznaczałoby nie tylko pewne uproszczenie problemu, ale niesprawiedliwą ocenę zachowań wielu ojców. Te negatywne oceny mogłyby dodatkowo pogrążyć niektórych mężczyzn w braku pewności siebie, poczuciu winy czy też w lęku przed odpowiedzialnością za innych. Kryzys ojcostwa spowodowany jest dziś niewatpliwie przez cały splot procesów i przemian cywilizacyjnych: społecznych, politycznych, ekonomicznych, kulturalnych i religijnych, na które pojedynczy mężczyzna nie ma wpływu ${ }^{34}$.

Dzieci potrzebują ojców. Dlatego ojcom nie wolno już dłużej pozostawać na marginesie. Nieobecność ojca musi się wreszcie skończyć. Nasze społeczeństwo wychowane bez ojców musi nareszcie uznać wartość ojcostwa. Społeczeństwo potrzebuje autentycznych ojców. Z powodu degradacji „ojcowskiej misji” mężczyzny cierpią nie tylko kolejne pokolenia dzieci, ale także całe społeczeństwo. Bez uznania roli ojca mężczyźni nie mają żadnej motywacji do włączenia się we wspólnotę społeczną jako świadomi swojej odpowiedzialności obywatele, do konstruktywnego wykorzystywania swoich zdolności dla dobra ogółu i opanowania agresji, uczynienia czegoś dla przyszłego pokolenia. Ojcostwo nie może być budowane na władzy starszych nad młodszymi, ale na trosce, służbie, odpowiedzialności, partnerstwie i miłości bezinteresownej. Aby dorosły mężczyzna mógł cieszyć się ojcowskim autorytetem u młodych, musi sobie na niego zapracować. Ojcostwo może być dojrzałe tylko wówczas, kiedy bywa ofiarowane dzieciom własnym i cudzym w pełnej wolności wewnętrznej ${ }^{35}$.

\footnotetext{
33 Tamże, s. 7-8.

34 Tamże, s. 39.

35 Tamże, s. 69-70.
} 
Pomimo przytłaczającego rozkładu życia wokół nas w pewnym sensie te czasy należą do najlepszych i najgorszych. Mimo że wiele dzieci dorasta bez ojców, wielu ojców w nowy sposób stawia teraz dzieci jako priorytet. Ojcostwo samo w sobie jest kierunkiem ${ }^{36}$.

Krzysztof Arcimowicz, oprócz takich typów ojców, jak ,żywiciel rodziny”, „głowa rodziny” czy „srogi wychowawca”, stanowiących tradycyjny paradygmat męskości i ojcostwa, wymienia ojca - „partnera i opiekuna dziecka” oraz ojca „rodzącego", będących paradygmatem nowym ${ }^{37}$. Z osoby dominującej, stojącej na czele rodziny, ojciec stał się równoprawnym jej członkiem. $Z$ osoby chłodnej, często nieobecnej w życiu swoich dzieci przeobraził się w bardziej dostępnego rodzica, który nie wstydzi się swoich uczuć i ma czas, by zająć się wychowaniem. Ojcostwo we wzorze ojca „partnera” zostało uwolnione z dotychczasowej sztywności, rygoryzmu i autorytatywności ${ }^{38}$. Nowy paradygmat charakteryzuje równość płci. Ojciec może eksponować cechy męskie, ale także i kobiece. On już nie dominuje, lecz współdziała. Jest partnerem dla swojej żony i dzieci ${ }^{39}$.

Zmierzch patriarchatu stał się początkiem epoki nowego ojcostwa ${ }^{40}$. Przyjście na świat dziecka wielu mężczyzn odbiera dzisiaj jako wielkie osobiste wyzwanie. Współczesny mężczyzna, nie mając perspektywy wskazania swoim dzieciom wielkich dóbr materialnych, lepiej rozumie, że może im ofiarować większy dar - samego siebie: swój czas, czułość, życzliwość, troskę, wsparcie, ofiarność - słowem ojcowską miłość. W ostatnich latach widzimy kierunek propagujący prawdziwego mężczyznę jako kogoś nastawionego opiekuńczo. Niektórzy ojcowie i mężowie - w większości młodzi - postanawiają rozwijać te cechy w swoim życiu. Ta przemiana jest znakiem nadziei dla wielkiej liczby wzrastających dzisiaj dzieci. Współczesne ojcostwo może być w pewnym sensie bardziej autentyczne od ojcostwa w przeszłości. Oparte jest bowiem przede wszystkim na osobistych wartościach, świadomie zdobytych w pracy nad sobą oraz w relacji do kobiety i dzieci ${ }^{41}$.

Każde narodziny dziecka stawiają tak ojca, jak i matkę wobec faktu, że otwiera się przed nimi zupełnie nowa karta życia. Ma ona być zarazem faktycznym sprawdzianem wartości, których rodzice są przykładem, a jednocześnie szansą ich własnego rozwoju społecznego, psychicznego i moralnego ${ }^{42}$.

Dziecko bowiem, poprzez swą świeżą i niekonwencjonalną interpretację wielu zjawisk, daje każdemu, kto chce je zrozumieć, bardzo dużo okazji do za-

${ }^{36}$ K. Canfield, Serce ojca. Jak być dobrym ojcem, Warszawa 2007, s. 19.

${ }^{37}$ K. Arcimowicz, dz. cyt., s. 204-210; por. tenże, Wizerunek ojca w polskich mediach na przetomie XIX i XX wieku, w: M. Fuszary (red.), Nowi mężczyźni? Zmieniajace się modele męskości we wspótczesnej Polsce, Warszawa 2008, s. 124-141.

${ }^{38}$ I. Chmura-Rutkowska, J. Ostrouch, Mężczyźni na przełęczy życia. Studium socjopedagogiczne, Kraków 2007, s. 227.

${ }^{39} \mathrm{~K}$. Arcimowicz, Wizerunek ojca, s. 124.

${ }^{40}$ E. Badinter, XY tożsamość mężczyzny, Warszawa 1993, s. 148.

${ }^{41}$ J. Augustyn, dz. cyt., s. 70.

42 J. Witczak, Ojcostwo bez tajemnic, Warszawa 1987, s. 25. 
stanowień i przemyśleń, co wpływa na poszerzenie skali spojrzenia każdego człowieka na otaczającą rzeczywistość i prawa nią rządzące ${ }^{43}$. Dziecko, ze swym niepowtarzalnie pięknym i bogatym światem przeżyć, może stać się wielkim motorem dojrzewania psychicznego każdego człowieka, który z nim przebywa i chce wniknąć w jego psychikę ${ }^{44}$.

Współczesne przemiany ról rodzicielskich nie są procesem prostym i klarownym (dalekim od zakończenia), a ścieranie się „nowego” ze „starym” w rodzinie wprowadza chaos w rozumienie i pełnienie funkcji rodzicielskich. Zmiana roli i pozycji kobiety w rodzinie powinna naturalnie implikować zmianę roli mężczyzny w familijnym stadle. Tym naturalnym dążeniom należy jednak pomóc. Trzeba dyskutować o konieczności podjęcia przez mężczyznę nowych obowiązków, upowszechnić wiedzę o ojcostwie, wyjaśnić znaczenie ojca w wychowaniu dzieci, nadawać wartość współczesnym elementom roli rodzinnej ojca. Wieloletnie milczenie na ten temat i deprecjonowanie znaczenia ojca (przerywane tylko feministycznymi okrzykami: „Ludwiku do rondla”) nie ułatwiło mężczyźnie (szczególnie starszemu) zrozumienia jego znaczenia i miejsca w dzisiejszej rodzinie. Tylko ojcowie młodzi (i też nie wszyscy, zjawisko dalekie jest od powszechności) - mniej już obciążeni tradycjami patriarchalnych układów rodzinnych, rozwijający swój związek małżeński na partnerskich, egalitarnych stosunkach - łatwiej przyjmują różne funkcje opiekuńcze w odniesieniu do dziecka. Część z nich rozumie ten prosty fakt, że żona też pracuje i trzeba jej pomóc w wychowaniu, inni podchodzą do tych czynności z powagą, nadając dziecku ogromną wartość. Jego wychowanie i kształtowanie od najmłodszych lat jawi się takim ojcom nie tylko jako świadomy obowiązek, ale jako współczesny przywilej mężczyzny, z którego nie chcą zrezygnować. Ci młodzi mężczyźni zaczynają więc dzisiaj wcielać w życie piękne postawy ojcowskich zachowań, o których pisał Benjamin Spock:

Przyjdzie wielki dzień, kiedy ojcowie będą:

- uważać opiekę nad dzieckiem za równie dla nich ważną, jak praca i kariera zawodowa,

- szukać takiej pracy i tak układać harmonogram zajęć, żeby mieć wystarczająco dużo czasu na przebywanie z żoną i dziećmi,

- zastanawiać się - w dyskusjach z żoną na temat wyboru miejsca stałego pobytu po pierwsze nad tym, co będzie z korzyścią dla życia rodzinnego,

- nie zgadzać się na częste zmiany miejsca pobytu, narzucane im przez przedsiębiorstwa, w których pracują,

- dawać do zrozumienia w miejscach pracy, że traktują bardzo poważnie swoje rodzicielskie obowiązki i mogą od czasu do czasu zwalniać się, gdy będą potrzebni w domu - tak jak zawsze robią to matki,

- skłaniać innych ojców w swoim miejscu pracy, by zajęli podobne stanowisko ${ }^{45}$.

${ }^{43}$ Tamże, s. 25; zob. także: K. Pospiszyl, O miłości ojcowskiej, Warszawa 1986, s. 63.

${ }^{44}$ K. Pospiszyl, dz. cyt., s. 63.

${ }^{45}$ J. Witczak, dz. cyt., s. 11-12. 
Umacnia to nadzieję na powrót ojca do rodziny.

Jak mówi Elizabeth Badinter, nie troszcząc się o niuanse, ogłasza się to zmierzch, to renesans ojcostwa. Rzeczywistość jest tak różnorodna, że namalowanie portretu dzisiejszego typowego ojca wydaje się zadaniem niewykonalnym $^{46}$.

Hermann Bullinger próbuje zdefiniować ojcostwo, wprawdzie nie wprost, ale przez wyróżnienie kilku jego zasadniczych cech. Nowi ojcowie:

- podejmują swoją rolę aktywnie i świadomie,

- coraz częściej deklarują gotowość zajmowania się dziećmi na równi z kobietami,

- bardzo intensywnie przeżywają ciążę swojej żony,

- swój udział w porodzie traktują jako warunek zbudowania więzi z dziec$\mathrm{kiem}^{47}$.

Zgodnie z coraz powszechniej przyjmowanym nowym paradygmatem męskości, obecnie oczekuje się od mężczyzn pełnego zaangażowania w życie rodzinne i równego podziału obowiązków. Krytycznie ocenia się rolę ojca jako nieobecnego w procesie wychowania dzieci. Eksponuje się korzyści płynące z nowych doświadczeń, jakie przynosi angażowanie się mężczyzn w życie rodzinne i opiekę nad dzieckiem ${ }^{48}$.

Hermann Bullinger uważa, że podejmujący w nowy sposób swoją rolę ojcowie nie czynią tego z własnej inicjatywy. Motywacja do ukształtowania roli ojca jest wynikiem presji ze strony kobiet. Autor mówi wręcz o „ojcach z łaski kobiet”. Zmiany, jakie w nich zaszły, odbierane są jako coś obcego, wymuszonego, powierzchownego $0^{49}$. Autor mówi jednak, że przemiana roli ojca stwarza mężczyznom prawdziwą szansę na ich wyemancypowanie, a tym samym uwolnienie się od dawnego stereotypu męskości i ukształtowania zupełnie nowej tożsamości ${ }^{50}$.

Mężczyzna, tworząc własną tożsamość, opiera się na indywidualnym wyborze swojej drogi życiowej, zgodnie z prawem do samorealizacji ${ }^{51}$. Samorealizacja, rozumiana jako dążność do pełni człowieczeństwa dzięki wykorzystaniu własnego potencjału, staje się możliwa w oparciu na idei androgyniczności (dwupłciowości). Nowy paradygmat pozwala więc mężczyźnie na prezentowanie cech zarówno kobiecych, jak i męskich ${ }^{52}$.

Paradygmat ten akcentuje równość oraz partnerstwo mężczyzn i kobiet, uznając te wartości za fundamentalne w tworzeniu nowego ładu społecznego. Zawiera koncepcję samorealizacji i androgyniczności rozumiane jako dążenie do

${ }^{46}$ E. Badinter, dz. cyt., s. 149.

${ }^{47}$ H. Bullinger, dz. cyt., s. 14.

${ }^{48}$ M. Dąbrowska-Wnuk, Na drodze ku nowemu ojcostwu, w: E. Mandal (red.), W kręgu gender, Katowice 2007, s. 133-134.

${ }^{49} \mathrm{H}$. Bullinger, dz. cyt., s. 18.

${ }^{50}$ Tamże, s. 22.

${ }^{51}$ M. Dąbrowska-Wnuk, dz. cyt., s. 132.

${ }^{52}$ Tamże, s. 131. 
pełni człowieczeństwa. Mężczyzna nie walczy z istniejącą w nim kobiecością. Eksponowanie zarówno cech męskich, jak i kobiecych pozwala mężczyźnie osiągnać pełnię indywidualnego potencjału człowieka. Jego dewizą życiową staje się współdziałanie, a nie dominacja. Jest on partnerem dla kobiet i dzieci ${ }^{53}$.

Zmiana, by cechować się trwałością, nie może zostać ograniczona wyłącznie do modyfikowania zewnętrznych przejawów zachowań mężczyzn, lecz musi dotyczyć także ich osobowości. Zmiany te są możliwe tylko wtedy, gdy będą miały charakter całościowy. Zmiana w sposobie pełnienia roli ojca musi być poprzedzona zmianą nie tylko wizerunku samego mężczyzny, ale także integralnie z nimi związanych: kobiecości i macierzyństwa. Role mężczyzny i kobiety dopełniaja się wzajemnie, co oznacza, że mogą ulec zmianie tylko wspólnie i jednocześnie, w przeciwnym bowiem razie role mężczyzny i ojca będą nadal we wzajemnym konflikcie ${ }^{54}$.

\section{Zakończenie}

Ojcostwo jest we współczesnym świecie zagubione. Oczywiście nie ojcostwo każdego poszczególnego ojca. Nie ma właściwego rozumienia roli ojca, więc tym bardziej nie może być jej właściwego wypełniania ${ }^{55}$.

Doświadczenie ojcostwa, stanowiące swoiste wyzwanie dla współczesnych mężczyzn, poddane zostaje sukcesywnie na przestrzeni wielu lat daleko idącym przeobrażeniom. Obejmują one sposób sprawowania funkcji rodzicielskiej w wyniku poszerzania jej o nowe, nieznane dotąd aspekty ${ }^{56}$.

Ocalenie rodziny jest możliwe tylko przez odnowę ojcostwa - powrót do wzorca czy stworzenie nowego człowieka i nowych relacji damsko-męskich, dających szczęście.

Współcześnie nie istnieje żaden klarowny i godny akceptacji wzorzec ojca. Człowieka kształtuje wychowanie i samowychowanie. Do ojcostwa trzeba więc wychowywać. Trzeba stworzyć u młodych chłopców fascynację, żeby zapragnęli w swoim życiu być ojcami, zrobić karierę ojca ${ }^{57}$.

Jak zauważa Elizabeth Badinter, macierzyństwo jest darem, a nie natura. Obalenie pewnego mitu, zgodnie z którym wyłącznie matki - z racji uwarunkowań biologicznych - są w stanie sprawować opiekę nad dzieckiem, do pewnego stopnia wyrównało szanse obojga rodziców ${ }^{58}$.

${ }^{53}$ K. Arcimowicz, Przemiany męskości w kulturze wspótczesnej, w: M. Fuszary (red.), dz. cyt., s. 22.

${ }^{54}$ M. Dąbrowska-Wnuk, dz. cyt., s. 134-135.

${ }_{55}$ J. Pulikowski, Warto być ojcem, Poznań 2002, s. 147-148.

${ }^{56}$ M. Dąbrowska-Wnuk, dz. cyt., s. 129.

${ }^{57}$ J. Pulikowski, Warto być..., s. 156, 158.

${ }^{58}$ M. Dąbrowska-Wnuk, dz. cyt., s. 135. 
Nowy paradygmat powinien więc łączyć to, co sprawdzone, a wynikające z tradycji, z nowymi rozwiązaniami. Oznacza to dla mężczyzn swobodę w odkrywaniu i wyrażaniu kobiecej natury swojej osobowości bez przymusu rezygnowania z męskości. Wówczas idea samorealizacji i androgynii będzie miała szansę ujawnić się w nowym sposobie wypełniania roli ojca, będącego dla dziecka nie tylko autorytetem, uczącym je samodzielnego funkcjonowania w świecie ryzyka i zagrożeń, ale także czułym i troskliwym doradcą i opiekunem ${ }^{59}$.

\section{The fatherhood in the contemporary world (Summary)}

In present times we are witnessing the crisis of fatherhood. This crisis stems not only from the behaviour of men themselves but it is largely connected with the questioning of the role of the husband and father which men should have as well as the crisis of marriage and family which are the fundamental principles of mature and responsible fatherhood. In the culture today most men follow to some degree the model of a passive, uninvolved and absent father. This absence must finally end. Our society, which has been brought up without fathers, must finally accept the value of fatherhood. The end of patriarchy has become the beginning of a new fatherhood epoch, a new paradigm of masculinity. This paradigm focuses on the equality and partnership of men and women, accepting these values as fundamental in creating a new social order. It includes the concept of self-fulfillment and androgyny meant as aiming at complete humanity. Saving the family is possible only by the revival of fatherhood - the return to the model or creating a new human and new men-women relations which give happiness. A human is created through upbringing and self-upbringing. Therefore to be the father one must be brought up to this role.

59 Tamże, s. 132. 